Ethiopian Journal of Environmental Studies \& Management 9(6): 760 - 768, 2016.

ISSN:1998-0507

Submitted: July 31, 2016

doi: http://dx.doi.org/10.4314/ejesm.v9i6.8

\title{
CONTAMINATION LEVELS OF DOMESTIC WATER SOURCES IN MAIDUGURI METROPOLIS, BORNO STATE, NORTHEAST, NIGERIA
}

\author{
*JIMME, M.A.,1 BUKAR, W.M. ${ }^{2}$ AND MONGUNO, A.K. ${ }^{1}$ \\ ${ }^{1}$ Department of Geography, University of Maiduguri, Borno State, Nigeria \\ ${ }^{2}$ Department of Geography, Kashim Ibrahim College of Education, Maiduguri, Borno State
}

\begin{abstract}
The study examines the levels of contamination of domestic water sources in Maiduguri Metropolis area of Borno State based on their physicochemical and bacteriological properties. It was informed by the global concern on good drinking water quality which is an indicator of development level; hence the focus on domestic water sources to ascertain safety as water from unhygienic sources pose serious health challenges. The study dwelt on physicochemical and bacteriological parameters believed to have health implications. Experimental design was adopted, where water samples derived from four different sources i.e. from treated surface water, deep boreholes, wash boreholes and harvested rainwater were tested in the laboratory for $\mathrm{pH}$, total dissolved solids (TDS), total hardness $(\mathrm{TH})$, aluminium (Al), arsenic (As), cadmium (Cd), chromium (Cr), cupper (Cu), cyanide (Cn), lead $(\mathrm{Pb})$, fluoride $(\mathrm{Fl})$ and nitrate $\left(\mathrm{NO}_{3}\right)$. Also tested were faecal coliform (E. coli) and total coliform counts in the samples. The results showed that levels of physicochemical parameters are within the acceptable limit of WHO mostly in samples from deep boreholes and treated surface water sources. Samples from wash boreholes and harvested rainwater show escalated levels of some of the physicochemical parameters. The two sources also did not yield zero E. coli count. The study concludes that water from wash boreholes and harvested rainwater sources potent health risk. Thorough epidemiological study to determine health implications of drinking water from wash boreholes and harvested rainwater in the study area was offered as recommendation.
\end{abstract}

Key Words: Domestic Water, Contamination, Boreholes, Diseases

\section{Introduction}

Water is the single most important prerequisite for all forms of life on the planet earth. Good quality drinking water is essential to the health and well-being of all people (WHO, 2008). One of the targets of the Millennium Development Goals (MDGs), which Nigeria and other nations worldwide have adopted, is to at least reduce by halve the proportion of people without sustainable access to safe drinking water and basic sanitation (Kahinda et al., 2007). In addition, the World Health Organisation (WHO) mandates its member states to consider it as a right for all people, irrespective of 
their stage of development and their social and economic status, the access to an adequate supply of safe drinking water (Al-salaymeh and Al-Khatib, 2011). Fresh water, once considered as a common resource, is now fast becoming a rare and scarce commodity (Amin and Han, 2009). Urbanization has resulted in overexploitation of ground water, reduction in open soil surface and water infiltration rate and a resultant deterioration in water quality. The condition in the rural areas is even worse. Urban development and increasing water demand are putting stress on existing water resources (Bumba et al., 1991; Dwivedi and Bhadauria, 2009). It has been estimated that worldwide, water consumption is rising at double the rate of population growth (Garthwait et al., 2009).

Drinking water is usually sourced from underground and surface water sources, as well as other non conventional sources such as direct interception of rain from roofs. These sources vary in terms of vulnerability to contaminants. The variation could be due to environmental factors such as nature of geology and soil and atmospheric pollutions.Therefore it isimperative to examine sources of domestic water supply in communities to ascertain both physicochemical and bacteriologicalquality for drinking and other domestic purposes.

Consumption of water contaminated by disease causing agents (pathogens) or toxic chemicals can cause health problems like diarrhoea, cholera, typhoid, dysentery, and skin diseases (WHO, 2004). According to a United Nation's report, an estimated $80 \%$ of all diseases and over one third of deaths in developing countries are caused by the consumption of contaminated water and on average, as much as one tenth of each person's productive time is wasted due to illness from water related diseases (UNICEF, 1995). Therefore universal access to safe drinking water and sanitation are essential steps in reducing these preventable diseases, hence the cause for concern.In Nigeria, the report of the Rapid Assessment of Drinking Water Quality (RADWQ) shows that, nationally, only $30 \%$ of the water sources were in the very low risk to health category, compared to the $78.7 \% \mathrm{WHO}$ Guideline Value (WHO/UNICEF, 2006). Therefore, it is imperative to take a close look at qualities of water sources; particularly in Maiduguri which is located within a semi-arid region of North-eastern Nigeria where water for domestic and other uses always remain a challenge, and hence, people seem to exploit all possible sources without due regard to safety. This paper therefore dwells on testing some physicochemical and bacteriological parameters that have health risks from different water sources to determine the sources with greater risks.

\section{Purpose of the Study}

The study is aimed at examining the contamination levels of some water sources in Maiduguri metropolitan Area of Borno State with the view of ascertaining safety for drinking. It was originally designed to compare domestic harvested rainwater with conventional water sources; hence the available data permitted the expansion of scope. Specifically, the objectives were to test for physicochemical and bacteriological parameters from samples derived from the water sources; and to compare the 
parameters values with thestandard limits of WHO drinking water quality guidelines.

\section{The Study Area}

Maiduguri is located at the Northeastern corner of Nigeria on Latitude $11^{\circ} 40^{\prime} \mathrm{N}$ and $11^{\circ} 44^{\prime} \mathrm{N}$ and Longitude $13^{\circ} 05^{\prime} \mathrm{E}$ and $13^{\circ} 14^{\prime}$ E. It covers a total area of $543 \mathrm{~km}^{2}$, which makes it the largest city in the Northeastern region of Nigeria (Daura, 2002). Maiduguri Urban now extends to four Local Government Areas: Maiduguri Metropolitan, Jere, Konduga and to a smaller extent Mafa local government areas (Kawka, 2002). The area is within the vast open plain which is flat or gently undulating, developed on young sedimentary rocks of the Chad formation. This relatively flat terrain is sloping towards the Lake Chad and has an average relief ranging between $300 \mathrm{~m}$ and 600m above sea level (Daura, 2001 and Online Nigeria, 2003). Maiduguri lies on, and at the bottom of the Bama Ridge which runs in a Northwest/Southeast direction from the Niger boundary to the Cameroun Mountains. The topography and landscape to its Northeast and Southwest is featureless and flat. The area is drained by River Ngadda and the Ngadda Bul as its tributaries (Bukar, 2006).

Maiduguri is located in the Sudan Savannah region of Nigeria, south of the Sahara. It is characterized by low precipitation $(650 \mathrm{~mm})$, high evaporation and perennial water shortage (Daura, 2001). The highest in rainfall in August and greater part is received during the month of July, August and September.

There are four identified seasons in the area which include the rainy season, (June to September) Harvest season (September to November), Harmattan or Cool season (December to February) and hot season (March to May) (Waziri, 2009). Generally the mean monthly temperature is always above $20^{\circ} \mathrm{C}$ but the daily extremes vary in a wide range reaching up to $47^{\circ} \mathrm{C}$ in April. Daily temperature may occasionally exceed $40^{\circ} \mathrm{C}$, while the night temperatures are high but lowered in the early morning hours. The climate of the area is affected by the North East trade winds and the South West monsoons originating from the Sahara and the Altantic Ocean. The soil of Maiduguri and environs may be classified into sands of aeolian origin and the beach ridge sediment, vertisol or lagoonal clay and fluvisol and clay soil of alluvial deposit. There are also the brown and reddish brown, regosols, hydromorphic and alluvial soils which are favorable for agricultural activities of many types (Daura, 2001). The 2006 National Population and Housing Census gave the population of Maiduguri as 621,492 with a density of 1145 persons per square $\mathrm{km}$ which makes it the most densely populated city in North Eastern Nigeria (Waziri, 2009). 


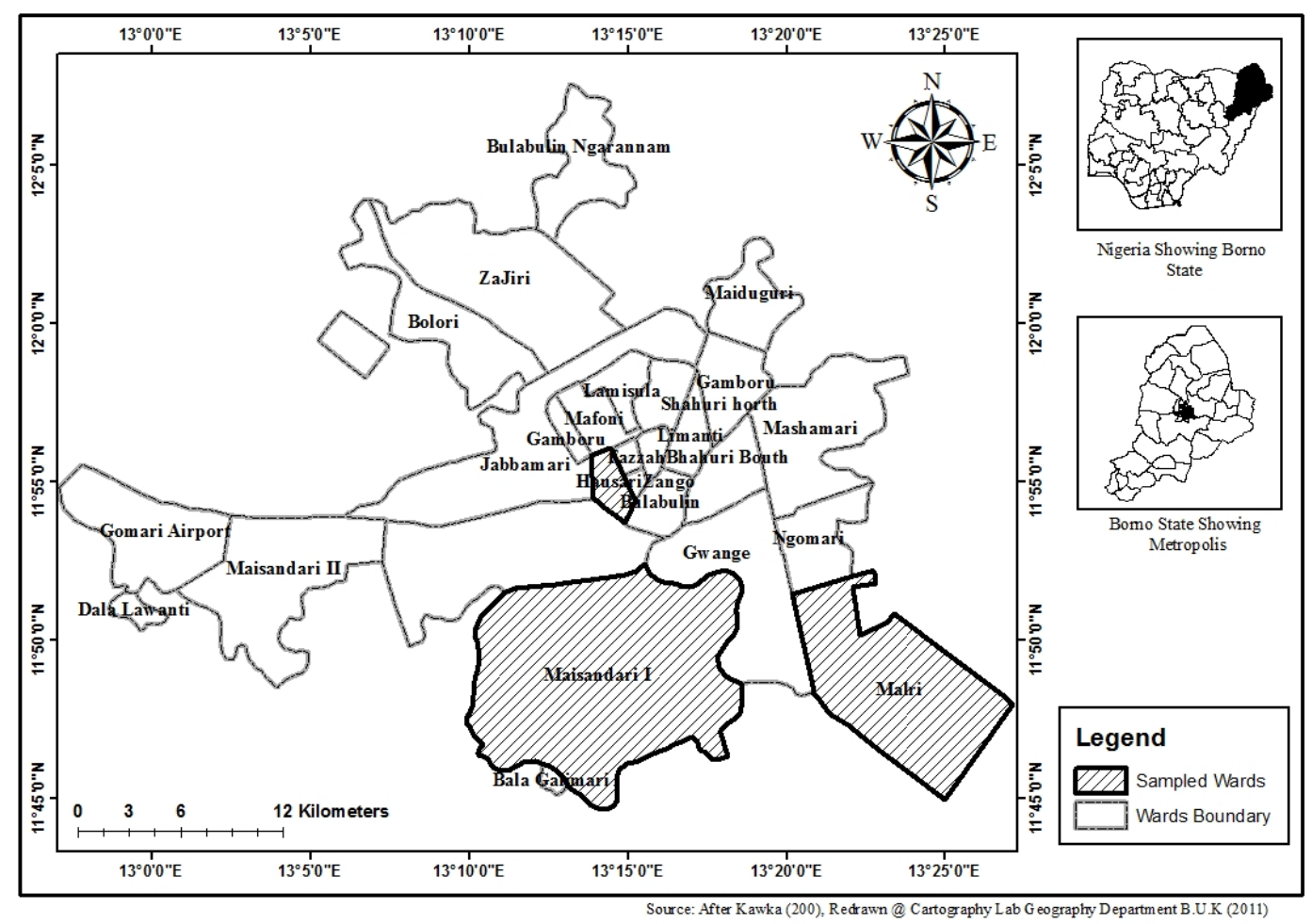

Figure 1: Maiduguri township showing wards where the samples were drown

\section{Materials and Methods}

The study design is experimental which involved collection of water samples and laboratory analysis for quality values of parameters considered in the water quality analysis which were given in $\mathrm{mg} / \mathrm{l}$ or coliform count $/ 100 \mathrm{ml}$ of sample. The parameters monitored were $\mathrm{pH}$, total dissolved solids (TDS), total hardness (TH)-(physical parameters); aluminium ( $\mathrm{Al})$, arsenic (As), cadmium $(\mathrm{Cd})$, chromium $(\mathrm{Cr})$, cupper $(\mathrm{Cu})$, cyanide $(\mathrm{Cn})$, lead $(\mathrm{Pb})$, fluoride $(\mathrm{Fl})$ and nitrate $\left(\mathrm{NO}_{3}\right)$-(chemical parameters); faecal coliform (E. coli) and total coliform (bacteriological parameters). These parameters were selected based on health concerns and relevance in the study area, as well as economic feasibility. Data from documentary sources were also used. These are mandatory standard limit values of water quality constituents of WHO Water Quality Guidelines 2008 and that of Nigerian Standard Organisation (2007).

Three wards were purposively sampled, taking into cognizance location within city center and periphery as well as residential density. Thus Hausari represents high density city center; Mairi medium density suburb; while Maisandari is mainly low density GRA. Five samples were randomly taken in each of the three wards within the period, making the total of fifteen. These are sources from treated surface water, deep boreholes, wash boreholes and harvested rainwater. The sources were arrived at considering the major domestic water supply sources in the metropolis (Kagu and Maidugu, 2001; Bukar, 2006).The five samples each were taken in 
purposively selected houses to ensure representation of all water sources in the area. The samples were generated within three months in the rainy season (July, August and September). Total number of samples analysed was 45 , i.e. 15 samples each month.

Collection of water samples and analysis procedure were guided by the APHA (1992) standard. The $\mathrm{pH}$ and TDS levels were measured using portable $\mathrm{pH}$ meter (combo type) and TDS meter (model FE20). Although, separate equipment were used for the physical parameters same sample sets were used. The portability of the equipment made that possible. The concentration of chemical elements and compounds and $\mathrm{TH}$ (as $\mathrm{CaCO}_{3}$ ) were determined using inductively coupled plasma - optical emission spectrometer (ICP - OES). Total Coliform Bacteria and E. coli counts were determined by the procedure of membrane filtration.

It was ensured that all samples were conveyed to the laboratory within 6 hours of collection to avoid microbial multiplication.The results of the laboratory analysis were further summarised to obtain the simples means of each parameter in the samples from all sources.

\section{Results and Discussion}

The results of the laboratory analysis is summarised in table 1 showing mean values of the parameters in the samples of the different water sources and corresponding standard values of WHO (2008) and SON (2007).

Table 1: Mean concentration values of water quality parameters of four water sources and the standard values

\begin{tabular}{|c|c|c|c|c|c|c|}
\hline Parameter & $\begin{array}{l}\text { Treated } \\
\text { Surface } \\
\text { Water }\end{array}$ & $\begin{array}{l}\text { Deep } \\
\text { Borehole }\end{array}$ & $\begin{array}{l}\text { Wash } \\
\text { Borehole }\end{array}$ & $\begin{array}{l}\text { Harvested } \\
\text { R/water }\end{array}$ & $\begin{array}{l}\text { WHO } \\
\text { Standard } \\
\text { Limits } \\
\text { (WHO, } \\
\text { 2008) }\end{array}$ & $\begin{array}{l}\text { Nigerian } \\
\text { Standard } \\
\text { (SON, } \\
\text { 2007) }\end{array}$ \\
\hline $\mathrm{pH}$ & 5.82 & 7.09 & 6.23 & 6.78 & $6.5-9.5$ & $6.5-9.5$ \\
\hline TDS (mg/l) & 38.8 & 105.0 & 519.0 & 93.5 & 1200 & 500 \\
\hline $\mathrm{TH}(\mathrm{mg} / \mathrm{l})$ & 112.0 & 253.0 & 482.0 & 133.1 & 200 & 150 \\
\hline $\mathrm{Al}(\mathrm{mg} / \mathrm{l})$ & 0.56 & 0.07 & 0.44 & 0.15 & - & 0.2 \\
\hline As $(\mathrm{mg} / \mathrm{l})$ & ND & ND & 0.21 & 0.006 & 0.01 & 0.01 \\
\hline $\mathrm{Cr}(\mathrm{mg} / \mathrm{l})$ & 0.05 & ND & 0.18 & 0.068 & 0.05 & 0.05 \\
\hline $\mathrm{Cu}(\mathrm{mg} / \mathrm{l})$ & 0.77 & ND & 0.42 & 0.072 & 2 & 1 \\
\hline $\mathrm{Cd}(\mathrm{mg} / \mathrm{l})$ & ND & ND & 0.15 & ND & 0.003 & 0.003 \\
\hline $\mathrm{Pb}(\mathrm{mg} / \mathrm{l})$ & ND & ND & ND & 0.0007 & 0.01 & 0.01 \\
\hline $\mathrm{Fl}(\mathrm{mg} / \mathrm{l})$ & 0.22 & ND & 0.61 & 0.026 & 1.5 & \\
\hline $\mathrm{No}_{3}(\mathrm{mg} / \mathrm{l})$ & 0.25 & 0.06 & 5.52 & 2.50 & 50 & 50 \\
\hline TC $(\mathrm{cfu} / 100 \mathrm{ml})$ & 2.2 & 2.6 & 10.3 & 5.7 & 10 & 10 \\
\hline E. $\operatorname{coli}(\mathrm{cfu} / 100 \mathrm{ml})$ & ND & ND & 3.5 & 1.4 & 0 & 0 \\
\hline
\end{tabular}

In terms of $\mathrm{pH}$, the mean values of samples from treated surface water and wash borehole sources are not within the permissible rangeas they are slightly acidic. The low $\mathrm{pH}$ in samples from wash borehole is obvious, but that from the 
treated surface water could be enhanced by samples derived from poorly stored water from household where hygienic practice might be compromised.Total dissolved solids (TDS) and total hardness (TH) mean values from wash borehole sources are high and exceeded the standards values, so also the mean value of TH from deep borehole samples.

The mean aluminum (Al) concentrations exceeded the standard value of $0.2 \mathrm{mg} / \mathrm{l}$ in surface water $(0.56 \mathrm{mg} / \mathrm{l})$ and wash borehole $(0.44 \mathrm{mg} / \mathrm{l})$ sources (Figure 1).

The high Al level in treated surface water is not unconnected with additives used in treatment which include aluminum compounds such as aluminum sulfate (alum), used in coagulation of dirt and other unwanted substances in water.

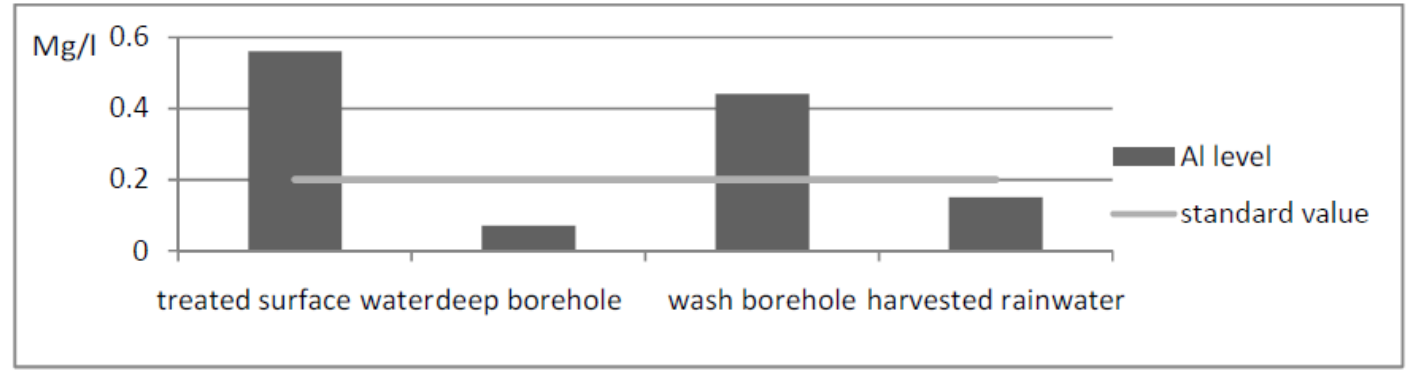

Figure 2: Aluminium levels in water sources against the standard level of SON.

As for arsenic, high level is recorded in samples from wash borehole, as the mean concentration from the source $(0.21 \mathrm{mg} / \mathrm{l})$ could not meet the standard limit of $0.01 \mathrm{mg} / \mathrm{l}$. chromium concentration is highin harvested rainwater $(0.68 \mathrm{mg} / \mathrm{l})$ and wash borehole $(0.18 \mathrm{mg} / \mathrm{l})$ where the values exceeded the standard limit of $0.05 \mathrm{mg} / \mathrm{l}$. As for the other two sources it was either not detected or were within the permissible limits (Figure 2).

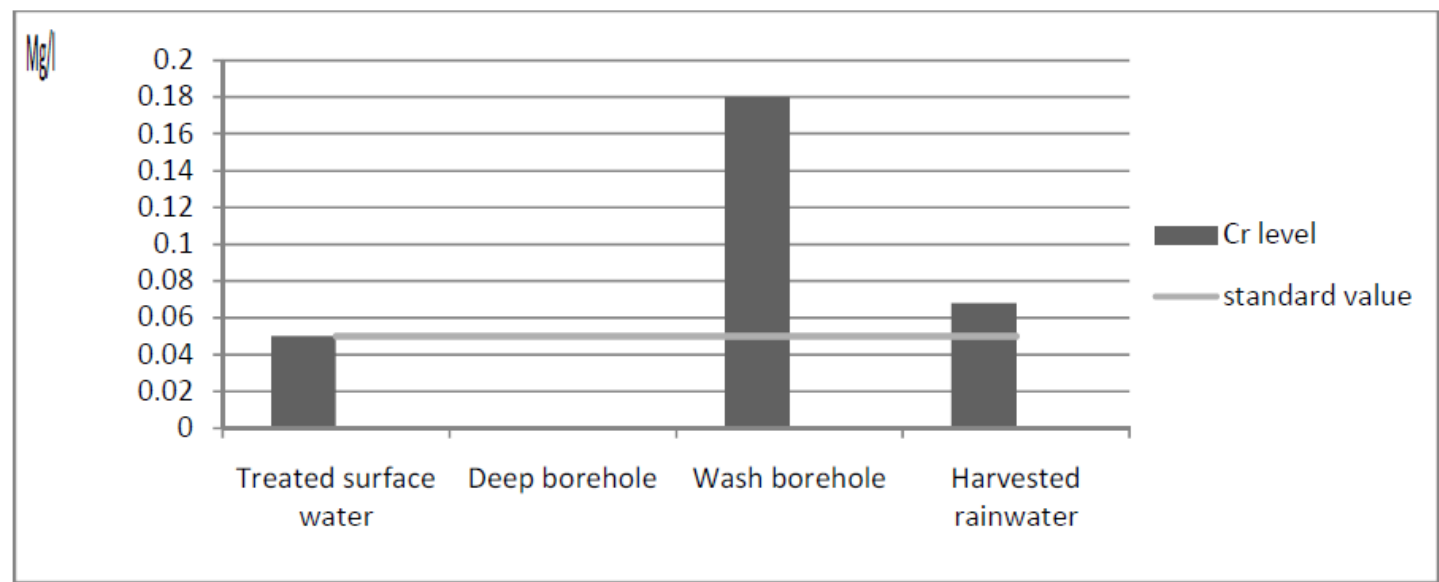

Figure 3: Chromium levels in water sources against the standard values. 
Copper $(\mathrm{Cu})$ was not detected in samples from deep borehole, though detected from other sources; the levels were far below the minimum standards. Cadmium (Cd) was detected only in wash borehole samples; the level is far above the standard value $(0.15 \mathrm{mg} / \mathrm{l}$ as against the standard value of $0.003 \mathrm{mg} / \mathrm{l})$. Traces of lead $(\mathrm{Pb})$ were detected only in samples from harvested rainwater, which can be traced to the roofs from where the rain was harvested as lead compound can be found in some paints used on roofs (Mosley, 2005). The lead level is far below the standard limit (Table 1). As forfluoride $(\mathrm{Fl})$, it was detected in samples from all sources except deep borehole, however in all the concentrations were within the acceptable limit. In the case of nitrate $\left(\mathrm{No}_{3}\right)$, it was recorded in samples from all sources only that the levels were far below the standard value of $50 \mathrm{mg} / 1$.

As for the bacteriological parameters, total coliform counts in samples from wash borehole have mean count little above the $10 \mathrm{cfu} / 100 \mathrm{ml}$ whereas the counts from the other sources were within the acceptable limit while zero e.coli count was recorded in samples from treated surface water and deep borehole sources. Since bacteria are likely causes of most common diseases, there is cause for concern on the two water sources.Common diseases such as cholera, typhoid fever and diarrhea are caused by bacteria (WHO, 2008; Yusha'u, Isa and Kawo, 2010). This is in addition to the fact that the two parameters were used as indicators to the presence of microbial pathogens in the water samples in compliance with conventional practice (Ahmed et al., 2010); Evans et al., 2006; New
Hampshire Department of Environmental services, 2003), thereby indicating level of health risks.

\section{Conclusion}

The study concludes that in terms of physicochemical parameters, most of the water sources are safe, although some parameters in treated surface water, wash borehole and harvested rainwater exceeded the standard values. The safest source in this regard is the deep borehole as in none of the samples recorded exceeded levels of the parameters. However in terms of the microbial parameters, only the samples from the treated surface water and deep borehole recorded zero coliform counts, therefore the levels in wash boreholes and harvested rainwater potent health risk. Hence, the needs for thorough epidemiological study to determine health implications of drinking water from wash boreholes and harvested rainwater in the study area.

\section{References}

Al-Salaymeh, A. and Al-Khatib, A. (2011). Quality of drinking water from rainwaterharvesting cisterns of Hebron city and factors affecting it. http://scholar.najah.edu/sites/schola r.najah.edu/files/conferencepaper/quality-drinking waterrainwater-harvesting-cisternshebron-city.pdf

Ahmed, W., Goonetilleke A. and Gardner, T. (2010). Implications of faecal indicatorbacteria for the microbiological assessment of roofharvested rainwater quality in Southeast Queensland, Australia. Canadian Journal of Microbiology 56(6): 471-479. 
Amin, M.T. and Han, M.Y. (2009). Roofharvested rainwater for potable purposes: application of solar collector disinfection (SOCO-DIS). Water Research vol.43Issue 20. Pp. 5225-5235. Accessed online via EBSCOhost.htm 2/27/2010.

APHA (1992). Standard Methods for the examination of water and wastewater. American Public Health Association, Washington DC

Bukar, W.M. (2006). The Viability and Sustainability of Rainwater Harvesting for Domestic Uses in Maiduguri Metropolis. Unpublished MSc dissertation, Department of Geography, University of Maiduguri.

Bumba, J., Kida, H.M. and Bunu, Z. (1991). 'Exploitation of underground water in theChad Formation: Maiduguri as a Case Study' in Gadzama, N.M., Adeniji, F.A., Richards, W.S. and Thambyaphillay, G.G.R. (eds) Arid Zone Hydrology and Water Resources. Ibadan: University Press. Pp 88-95.

Daura, M.M. (2001). "The Physical Environment and Development: A Study of Borno Region in Daura, M.M; Ogunnika, O; Irefin, D; and Balami, D. (eds) Environment and Development. Issues in SubSaharan African, Seminar Series, Vol.1. Faculty of Social and Management Sciences University of Maiduguri pp 35-47.

Daura, M.M. (2002). "Maiduguri" Atlas of Nigeria in Africa Atlasses, Bietlot, Belgium.Pp 148-149

Dwivedi, A.N. and Bhadauria, S.S. (2009). Domestic rooftop water harvesting: a casestudy.Journal of Engineering and Applied Sciences vol. 14 issue 6.EBSCO industries 2010.

Evans, C., Coombes, M., Dunstan, H. and Harrison, H. (2006). Roof harvestedrainwater - indicator organisms, water quality and risk assessment. School of Environmental and Life Sciences, University of Newcastle.

Garthwait, A., Curtis, M., Chan, A., Lopez, E., McNulty, J.P., Mills, C., Mitchell, J.Parent, N.M., Kersley, R., and G. Balter (2009)Water.eWaterTek Inc. Web Site. [Online] June 07, 2007. [Cited: June 10 , 2009.]http://www.ewatertek.ca/PDF /Credit\%20SuisseInvestment\%20Water\%20Research \%20Report-June\%202007.pdf.

Kahinda, J. M., Taigbenu, A.E. and Boroto, J. (2007). Domestic rainwater harvesting to improve water supply in rural South Africa.Physics and Chemistry of the Earth, Parts A/B/C Volume 32, Issues 15-18. Elsevier Ltd. Pp 1050-1057www.sciencedirect.com. Accessed 2/7/2011.

Kawka, R. (2002). The Physiognomic Structure of Maiduguri. In Kawka, R. (2002) from Bulamari to Yerwa Metropolitan Maiduguri. Interdisciplinary Studies on the Capital of Borno State, Nigeria.RudigerKoppeVerlag Kolon.p22-33

Mosley, L. (2005). Water quality of rainwater harvesting systems. SOPAC Miscellaneous Report 579.

New Hampshire Department of Environmental services (2003). 
'Fecal Coliform as an Indicator Organism'Environmental Fact Sheet.Concord, New Hampshire. www.des.nh.gov accessed 11/05/2012. Onlinenigeria, (2003); Borno State: Physical Setting.www.onlinenigeria.com/lin ks/ bornoadv.asp.

Standard Organisation of Nigeria (2007). Nigerian Industrial Standard: Nigeria Standard for Drinking Water Quality, SON, Abuja Nigeria.

UNICEF, (1995). Monitoring progress toward the goals of the world summit for children: a practical handbookfor multiple-indicator surveysUNICEF, New York.

Waziri, M. (2009). Spatial Pattern of Maiduguri City: Researchers' Guide, Kano City, Adamu Joji Publishers
WHO, (2004). Guidelines for DrinkingWater Quality, 3rd Edition, Volume 1: $\quad$ RecommendationsWHO, Geneva.www.who.int/water_sanitat ion health. Accessed 15/8/2010

WHO, (2008). Guidelines for Drinkingwater Quality. Third Edition Incorporating the First and Second Addenda, Volume 1Recommendations.WHO, Geneva www.who.int/water_sanitation_heal th

WHO/UNICEF (2006). Rapid assessment of drinking water quality (RADWQD), country report: Nigeria. RADWQD Technical SubCommittee, Abuja and WHO/unicef offices.

Yusha'u, M., Isa, A.N. and Kawo, A.H. (2010). Basic Microbiology. Kano: Benchmark publishers limited. 